\title{
HA-JOON CHANG AND AMARTYA SEN, TWO CONCEPTIONS OF DEVELOPMENT: THE ROLE OF THE STATE AND THE EXPANSION OF INDIVIDUAL LIBERTIES
}

\author{
HA-JOON CHANG E AMARTYA SEN, DUAS CONCEPÇÕES DE \\ DESENVOLVIMENTO: O PAPEL DO ESTADO E A EXPANSÃO DAS \\ LIBERDADES INDIVIDUAIS
}

Ana Luiza da Gama e Souza ${ }^{1}$

\begin{abstract}
This article presents the conceptions of development formulated by Ha-Joo Chang and Amartya Sen aiming to evaluate how they account to face the great challenges caused by the expansion of a global economic market. Chang and Sen propose different alternatives for understanding the notion of development. The first one builds a historical critique through which he intends to show the importance of the role of the State for economic development, in opposition to liberal and neoliberal recommendations in favor of free trade and non-intervention. The second is concerned with the deepening of social inequalities, on the one hand, and, on the other, the increase in wealth and accumulation, the development of technology and science, the consolidation of democracy and human rights, and formulates an extensive notion of human development focused on the agent, the individual, and the expansion of his freedom considered as a social commitment that makes it possible to face these deprivations. Both perspectives refute the argument that liberal policies are the only means of leading to development. However, Chang relies on historical evidence of protectionism as a political practice to counter this argument, reaffirming the role of the state, whilst Sen proposes a way to assess the various inequalities, empirically inferred, from the comprehensive analysis of the economy, social and political institutions, involving a multiplicity of institutions and actors beyond the state.
\end{abstract}

\section{KEYWORDS:}

Development; State; individual freedom.

\section{RESUMO}

Neste artigo apresenta-se as concepções de desenvolvimento formuladas por Ha-Joo Chang e Amartya Sen para avaliar como seus argumentos dão conta de enfrentar os grandes desafios da expansão economia de mercado global, Chang e Sen propõe alternativas diferentes de compreensão da noção de desenvolvimento. O primeiro constrói uma crítica histórica através

\footnotetext{
${ }^{1}$ Doutora em Filosofia (PPGF/UFRJ) e em Sociologia e Direito (PPGSD/UFF). Professora permanente do Programa de Pós-graduação em Direito - PPGD/UNESA. Avaliadora de cursos de graduação do Inep/MEC. Possui graduação em Filosofia pela UFRJ e em Direito, pela Universidade Cândido Mendes. Como pesquisadora na área de direitos humanos e desenvolvimento, com enfoque em direitos humanos e empresas, foi contemplada com fomento na chamada pública Universal - MCTIC/CNPqNº 28/2018 - e da FAPERJ na modalidade APQ1 e APQ2, no ano de 2016. A pesquisa desenvolvida desde 2009 tem como finalidade compreender a economia em sua relação com os direitos humanos, numa abordagem interdisciplinar que agrega a ética dos negócios, a filosofia da economia e a sociologia econômica. É coordenadora do grupo de pesquisa ODIHH (Observatório de Direitos Humanos), parceiro da Universidade Federal Fluminense e do Instituto de Direitos Humanos da Universidade de Connecticut / USA. É membro da Global Business and Human Rights Scholars Association (BR2R), do European International Studies Association e da Research Data Alliance (RDA).
} 
da qual pretende mostrar a importância do papel do Estado para o desenvolvimento econômico, em contraposição às recomendações liberais e neoliberais a favor do livre comercio e da não intervenção. $\mathrm{O}$ segundo preocupa-se com o aprofundamento das desigualdades sociais caracterizadas principalmente pela fome crônica, pela miséria e pelas privações, por um lado e por outro, o aumento da riqueza e a acumulação, o desenvolvimento da tecnologia e da ciência, a consolidação da democracia e dos direitos humanos e formula uma noção extensiva de desenvolvimento humano focado no agente, no indivíduo, e a expansão de sua liberdade, considerada como um compromisso social que possibilite o enfrentamento estas privações. Ambas as perspectivas refutam o argumento de que políticas liberais são os únicos meios de levar ao desenvolvimento. No entanto, Chang se apoia em evidências históricas do protecionismo como prática política para contrapor este argumento, reafirmando o papel do Estado, enquanto Sen propõe uma forma de avaliação das diversas desigualdades, inferidas empiricamente, a partir da análise compreensiva da economia, das instituições sociais e políticas, envolvendo uma multiplicidade de instituições e atores para além do Estado. Palavras-chave: desenvolvimento; Estado; liberdades individuais.

\section{PALAVRAS-CHAVE:}

Desenvolvimento; Estado; liberdades individuais.

\section{INTRODUÇÃO}

Economic globalization has changed the face of the world and brought challenges to the realization of human rights. This process, the result of the combination of several factors, has changed the political and social face of the world, shifted the center of power from the state to the economy, from the public space to the private space, and this structural translation has deeply impacted the ideal of development, an ideal of progress and prosperity focused on the human person, on the material conditions of his existence, and on the recognition of citizenship.

The process of development of the global market economy goes back a long way. The expansion of the market beyond national borders that characterizes it was one of the ingredients that made possible the passage from a mercantilist economy to mercantile capitalism and from there to a self-regulating and worldwide system. Between the beginning of the 17th century and the middle of the 18th century the foreign market grew seven times and this expansion had as a consequence the increase in the amount of capital that left the State monopoly and accumulated in the private sphere (HUME, 1955) and this "original" accumulation was one of the original conditions of capitalism as a system of production that leveraged by technological 
and scientific development resulted in what became known as the globalization of the economy or global market economy.

The relationship between the economy and the State, between the "success" of a market economy and the role of the State in this endeavor is problematic and has been the object of reflection since modernity, starting with David Hume, who criticized the monopolization of the economy by the State and defended that the appropriate space for the economy would be the private space, followed by Adam Smith. For both, this conception of economy had a moral purpose, that of the economy being a means for human development.

In contemporary times there has been a strong effort - practical and theoretical, or viceversa - to develop a market economy, whose bases would be in the idea of economic freedom. For neoliberal theorists, the economic space is the space of freedom, of non-interference by the State. Economic liberalism means economic freedom that is the faculty of the economic individual (self-interested and selfish) to choose among several alternatives opened by the market (PRIBAN, 1983, p. 618). Economic freedom means competition and in this logic the freedom of a competitor is only limited by the same measure of freedom of the other competitors.

From the social and economic inequality that in the mercantilist modernity was caused by an economy that monopolized the public space, we have moved to a monopoly of the economy by the private space that has been deepening and spreading inequalities, which requires new developmental perspectives, less founded on abstract theoretical models disconnected from reality and more attentive to the transformations of this reality caused by the global market economy and the political, social and human consequences of these transformations.

\section{CHANG AND THE ROLE OF THE STATE IN DEVELOPMENT: A HISTORICAL CRITIQUE OF THE NEOLIBERAL ECONOMIC MODEL}


Chang (2002) formulates a historical critique of the liberal economic model and its bet on free trade as the key to development. Chang's critique is located in the emergence of the new economic order and its foundations. This new order, which predominated from the 17 th century on, had Britain as its symbol, which was used as a historical example to justify the limitations and inefficiencies of mercantilism and the industrial success of a nation, leveraged by free trade.

Although there is not a single mercantilism, this economic model can be characterized by a set of ideas based on the same purpose: to accumulate wealth. Thus, the policies of the State, which combine the interests of the monarchs and merchants, are geared to ensure this purpose and follow the path of economic interventionism aimed at a favorable trade balance increasing exports and reducing imports - and to this end stimulate the development of manufacturing to promote the export of domestic products and thus avoid the import of foreign goods and the evasion of wealth.

In general terms, mercantilism can be described as an alliance between the State and the interests of capital, as a power that arises from accumulation. Mercantilist practice can be defined as one in which the profit interest is transferred to politics and in which the state acts like a capitalist, buying as cheaply and selling as dearly as possible. The state increases its power directly by increasing the public treasury, the result of intervention in economic practices, and indirectly, by collecting taxes from the population. (WEBER, 1968)

The expansion of the market beyond national borders was one of the ingredients that made possible the passage from a mercantilist economy to a capitalist economy, at first mercantile, and the success and advantages of this passage for the prosperity of nations were attributed to Great Britain that became the symbol of liberalism as an economic practice.

In 1989, the foundations laid by the new liberal order were reaffirmed with the Washington Consensus (1989), a set of recommendations and macroeconomic policies developed by John Williamson aimed at adjusting the macroeconomic policies of developing countries, especially Latin American countries, and that were consolidated as the "Good Policies and Good Institutions". Good macroeconomic policies are the liberalization of international trade, investment, privatization, and deregulation, restricting the power of the state to intervene in the economy. Good institutions include democracy as a value, strengthened property rights, market-oriented corporate governance, and politically independent financial 
institutions, as well as international organizations such as the WTO, the IMF, and the World Bank, the latter of which Amartya Sen criticized for doing far less than it could for development.

Faced with this reaffirmation of the strength of neoliberal foundations, Chang poses his question: Is this set of measures adequate for developing countries? Have developed countries reached their current level of development thanks to this set of measures, in particular free trade? Were liberal and neoliberal policies and institutions really the certainty of success for developed countries? Or did developed countries kick the ladder and hide the policies that led to their economic status? Chang advocates the latter hypothesis.

In perfect harmony with the recommendations of the Washington Consensus, argues Zhang, the neoliberal legend is that from the 17th century on, England put aside protectionist practices, a typically mercantilist measure, and adopted free-market and free trade. The success of the British laissez-faire approach, which made England the greatest economic power in the world, would have proved the superiority of liberal policies, which would have been legitimized and supported by the classical economic theories of Smith and Ricardo.

The myths that sustain this new liberal economic order, according to Zhang, are the laissez-faire domestic industrial policies, low barriers to international flows of goods, capital, and labor, and national and international macroeconomic stability supported by the gold standard that is supposed to lead to unprecedented economic development.

As the legend goes, Chang goes on to say, economic development went into reverse after the Second World War and, faced with the unstable context, countries returned to protectionism, erecting trade barriers. In 1932, England returned to protectionism and with it the world free trade system sank. With the Second World War, then, the liberal order collapses.

After the Second World War, free trade tried to get back on its feet, mainly with the GATT, but legend has it that the system succumbed to protectionism until the 1970s and 1980s, due to the maintenance of mistaken policies such as the one for infant industry. After the 1980s neoliberalism resurfaced preaching the myth of the minimal state, laissez-faire and openness to the international market, and the developing countries were pushed directly to the periphery of the world, which forced developing states to adopt neoliberal policies, especially that of Fernando Henrique in Brazil. 
From then on, the system was strengthened, with new international organizations preaching free trade, such as the WTO, and the new economic order or the new global economic system was created, with grandiose promises of ending poverty and hunger, an ideal that is still understood today.

England has always been always at the forefront when liberal regimes have emerged in the world, but its accession to the free trade system in 1860 was only possible, according to Chang, because England already enjoyed economic superiority conquered by protectionist policies and was therefore accompanied by the rest of the world.

Chang (2002) seeks proof in the economic history of some developed countries such as Great Britain, the United States and some small European economies such as Belgium and Holland, in addition to Japan and the newly industrialized countries of the Far East that these facts did not happen as the legend says. The method adopted by Chang centers the study on the 19th century and the beginning of the 20th century (1815 to 1914), a period in which most of the currently developed countries were undergoing the industrial revolution, although he makes some temporal concessions to Great Britain, Prussia, Japan, and France because of their historical peculiarities.

The purpose is to analyze a large number of countries, including countries outside the group of the most important economies to point out the proof that "good policies and institutions", especially free trade, recommended to developing countries were not the pillars that led developed states to the current stage of economic development, but that these policies recommended to developing countries actually have the purpose of hiding the path of success of developed countries, making it difficult for countries to access the real policies and institutions that led them to achieve development.

Keeping in mind that his critique is of historical bias, Chang makes some methodological considerations, reaffirming first of all the usefulness of historical, concrete and inductive approaches to economics and development, denouncing the predominant use by liberal and neoliberal economic theories of abstract and deductive models, which would have been used by developed states as tools to kick the ladder, deceiving developing countries and thus keeping the recipe for economic development in a safe place among developed countries and thus maintaining their power. 
Chang follows the argumentative line that the theoretical justification for kicking the ladder is found mainly in Adam Smith, in The Wealth of Nations, since he would be defending free trade as the path to progress, justification that would have been used by developed countries as the means to kick the ladder, while the historical reality of these countries shows that protectionist practices were used by all to ensure their internal market of free competition and thus increase the power of nascent industry and ensure economic development, i.e., development was the consequence not of free trade, but of the State's action in protecting the internal market.

In fact, argues Chang, the fostering of infant industry, protected by the state, was the key to the development of most nations, not the policies of free trade and free competition, alongside other practices and institutions spread as the path to prosperity.

The artifice of kicking the ladder, which has prevented peripheral states from achieving their development, is actually even more complex, because some of the institutions seen as potentially good and thus a necessary condition for development, such as a politically independent central bank, are actually only a consequence of development and not its cause. The thesis that the improvement of some institutions is recommended practice for development is actually another ploy to kick the ladder, since they are very costly and often irrelevant for the economic development of the country.

Chang draws inspiration from the historical approach of economist Friedrich List, who examined the trade and industrial policies of the most important countries in the Western world to support the nascent industry argument, according to which, faced with developed states, developing states are unable to perfect new industries without state intervention (protectionism) from which he concludes that free trade is only beneficial between countries at a similar level.

List, according to Chang, takes as an example, Great Britain, the cradle of liberalism as an economic and political theory, which, contrary to what has been told in economic literature, perfected the art of nascent industry that led to the desired prosperity. He argues that having already achieved a certain level of economic development through free trade and with a new national industry, Britain needed to adopt restrictive policies to protect its industry from free competition, using restrictive measures such as the Corn Law. In the same sense, the US, although it was influenced to adopt free trade as a practice, was the cradle of protectionism to 
later become the world leader in industry. After kicking the ladder, the US started to advocate free trade. It is a fact both for List and for Chang, who follows him, that free trade models have clear nationalistic purposes that aim to guarantee the secret of development.

Chang, through the analysis of the economic history of the currently developed countries, shows that all of them used the protection of infant industries in their catch-up period, with their own models of measures for the promotion of their industries, and that this reflects a persistent historical pattern that goes from the 18th century to the 20th century, from Great Britain to Japan and Korea. From this observation it cannot be inferred that all states achieved development exclusively because of these measures, but to protect infant industry are present in the development processes of currently developed states, and it is an extremely strong pattern to be disregarded. The importance of the role of the state in economic development is undeniable and the theories that hold free trade as the key to economic development cannot continue to ignore what reality brings as a contribution, notwithstanding all the epistemological difficulties that this statement brings.

\section{AMARTYA SEN AND DEVELOPMENT AS A PROCESS OF EXPANDING HUMAN FREEDOMS}

In different way, Amartya Sen's (2000) focus is on the inequalities deepened by the advance of the global market economy that has contrasted, on the one hand, a world of opulence" and, on the other, a world of deprivation in its broadest sense, such as chronic hunger, poverty, and the many forms of oppression that can be found in both poor and rich countries.

Sen's criticism is directed at the models that identify development with economic growth, because development is a process of expanding real human freedoms, those that are enjoyed by people. The growth of GDP and incomes can contribute to development to expand freedoms, as well as other factors that are indispensable to this expansion, such as education, health, civil rights, as well as industrialization and technological advancement. (SEN, 2000, p. 17). 
His concept of development as freedom means that everything that can contribute to the expansion of human freedoms and opportunities must be considered as the end of development, and not only some means chosen as relevant. At this point, Sen dialogues with Chang (2002), for whom the illusion of prosperity and economic development attributed to free trade did not lead to the development of peripheral economies and that, for Sen, is considered the very cause of inequalities and, thus, of the deprivation of freedoms, the opposite of development.

The evaluation of social inequalities targeting the functions and capabilities of people. In this sense, Sen defends an integrated analysis of economic, social, and political activities, involving a multiplicity of institutions, such as the market, the State, the laws, the media, among others, and agents, related in an interactive way and so provides an analysis that is intended to lead to public discussion about development and the practical reasons behind it. (SEN, 2000, p.11)

The proposal is to take individual freedom as a social commitment and thus development is seen as the expansion of this freedom and the elimination of deprivations that limit people's choices and opportunities to pursue quality of life, understood from two of Sen's concepts: the capabilities and the functionings, which represent the possible combinations between what people are able to do or be and what they do or are, respectively.

Capabilities reflect a person's freedom to choose to lead one life or another. The choices made by people are organized into vectors of functionings, while the set of all possible options of functionings for that person constitute their capability set, which are the set of substantive freedoms, whose expansion is the purpose of development.

The equality intended by Sen (2001) is not the equality of basic freedoms as proposed by John Rawls, nor the equality of resources intended by Ronald Dworkin, but the equality of freedom to perform functions, a freedom to choose the relevant functions for the well-being of the person, with quality of life measured by the ability to perform functions. Sen's analysis of development considers the freedoms of individuals as its basic constitutive elements and thus prioritizes the expansion of people's capacities to lead the kind of life they value.

Sen (2000, p. 25) argues that freedoms are not only taken as the primary ends of development, but as means, that is, as instruments for the promotion of substantial freedoms. 
Political freedoms, economic facilities, social opportunities, transparency mechanisms, and security are instrumental freedoms, which although distinct, are interrelated, which implies that they are mutually reinforcing.

The fundamental importance of individual freedom for Sen's concept of development is attributed to two reasons: evaluation and effectiveness. The first is that the success of a society must be evaluated in terms of the substantial freedoms actually enjoyed - this is where Sen differs from traditional evaluations using economic variables. The second is that freedom is not only the measure of success or failure in the development of a society, but it is a determinant of social effectiveness, which means that the more freedom the agent has, the greater his or her potential for transformation, a central issue for development.

In the approach of development as freedom everything that can contribute to the expansion of people's substantive freedoms must be considered, and the analysis - empirical of social, political, and economic institutions contribute to the development process. There is not a priority of the state or the market, but of everything that can contribute to the increase of individual substantive freedoms and the social commitment for this proposal to be realized.

The role of the market in development is the object of Sen's considerations. He recognizes the importance of market mechanisms for development but criticizes the tendency of the economy to move away from the value of substantial freedoms in favor of an ideal of economic freedom based on wealth and income, which, according to him, led to a depreciation of the role of economic mechanisms - the market - for the development understood from the point of view of freedoms.

Sen does not prioritize a competitive market concept over a centralized system or viceversa, because for him both can contribute to the expansion of freedoms, as long as freedom of choice is considered, since the importance of the market does not lie on its ability to generate efficient results - as without considering the means to achieve them, including restrictions or deprivations of opportunities in favor of these results, but to expand the choices, the opportunities, which does not depend on the efficiency of the market, but on the freedom to exchange without impediments. 
In this argument, he states his criticism of utilitarianism, which he develops in several of his works under the argument that utilitarian models consider the result of action, the welfare of the majority, which leads to a more empirical proposal for equality where there are substantial differences that must be evaluated and considered. (SEN, 2000, p. 43).

Economic facilities, such as the use of economic resources for consumption, production, or exchange are instrumental freedoms, as they contribute to the expansion of human freedom in general and to the quality of life and development. Freedom is not only the end of development, but its importance is also as a means, since instrumental freedoms, interrelated to other freedoms, together and chained together, contribute to a freer life, with fewer deprivations and restrictions, which increases the quality of life and contributes to development.

\section{FINAL CONSIDERATIONS}

The two points of view presented are marked by a common criticism directed at orthodox economic theories, which is that the economy as a means for social and human progress and development cannot be founded on abstract theoretical models totally removed from reality, but, on the contrary, it must start from and turn to historical and human reality, from facts, challenges, and lived experiences. However, Sen and Chang propose to understand development from different but, in a way, complementary points of view.

Chang uses the historical method to affirm the importance of state policies for economic development. His perspective of analysis is macro, that is, Chang sees development starting from the state, but defending in the end the importance of state intervention in the economy, as evidenced by the economic history of the currently developed states. His critique of neoliberal guidelines, founded on the ideals of free trade and non-intervention, translates into the "kicking the ladder" argument. These economic "good policies" were the necessary discourse to keep the peripheral states at the same level of development as they were before the emergence of the new economic order. In fact, according to Chang, free trade models have clear nationalistic purposes aimed at securing the secret of development, when in fact state efforts to protect nascent industry were the mechanism that led to development. 
Chang, however, understands development as economic growth and this growth, in his perspective, depends on state policies, on mechanisms to protect the national economy. Amartya Sen goes beyond a concept of development as economic growth, precisely his developmentalist approach seeks to expand the concept of development to identify it with the expansion of human freedoms. Sen argues that human development depends not only on the efforts of the state, but also of society and of all mechanisms that can contribute to overcoming deprivations, in a broad sense, and to the expansion of human freedom, both as an end of development, but also as an instrumental freedom that, interrelated to others, contribute to increasing freedom and thus individual quality of life and thus improve the social and political and lead to development.

The recognition that liberal policies are the only means to lead to development is all that Sen and Chan seek to counteract, but while Chang presents historical evidence of protectionist practices in the history of developed nations and thereby emphasizes the role of the state, Sen proposes a way to evaluate the various inequalities, empirically verified This allows an integrated analysis of economic, social, and political activities, involving a multiplicity of institutions, such as the market, the State, the laws, the media, among others, and agents, related in an interactive manner and that constitute a guide for public policies aimed at development.

\section{REFERÊNCIAS}

CHANG, Ho-Joon. (2002). Kicking Away the Ladder-Development Strategy in Historical Perspective. London: Anthem Press.

HUME, David (1955). Writings on Economics. Edited on an Introduction by Eugene Rotwein; with a new introduction by Margaret Shabas. Thomas Nelson and Sons Ltd. London.

OSER, J and BLACHFIELD, W. (1963). The evolution of economic thought. Harcourt Brace Jovanovich inc. USA;

PRIBRAM, Karl (1983). A history of economic reason. The Johns Hopkins University Press. London.

SEN, A. (1999a). Sobre ética e economia. Tradução de Lucas Teixeira Motta. Revisão técnica Ricardo Doninelli Mendes. Companhia das Letras. São Paulo; . (1999b). L'économie est une Science morale. La Découverte. Paris; 
. (2000). Desenvolvimento como liberdade. Companhia das Letras. São Paulo; . (2001). Desigualdade reexaminada. Record. São Paulo;

WEBER, M. (1968). História Geral da Economia. Tradução Calógeras Pajuaba. Editora Mestre Jou. São Paulo.

Data de Submissão: 18/02/2021

Data de Aceite: 23/03/2021 